\title{
Critical Thinking Through Distance Learning: An Analysis of Indonesian Open University
}

\author{
${ }^{* 1}$ Basidin Mizal, ${ }^{2}$ Rayhan Izzati Basith, and ${ }^{3}$ Tathahira \\ *1 UIN Ar-Raniry, Indonesia, basidinmizal0207@gmail.com \\ ${ }^{2}$ UIN Ar-Raniry, Indonesia, rayhanbasith@gmail.com \\ ${ }^{3}$ IAIN Takengon, Indonesia, tathahira92@gmail.com
}

\author{
Submitted: 12/03/2021 Revised: 09/04/2021 Accepted: 04/05/2021
}

How to cite this article: Mizal, B., Basith, R.I. \& Tathahira. (2021). Critical thinking through distance learning: An analysis of Indonesian Open University. IJELR: International Journal of Education, Language, and Religion, 3(1), 17-26.

\begin{abstract}
This study purposes the enhancement of Critical Thinking ability for students at Indonesian Open University or Universitas Terbuka (UT) and argues that critical thinking can be effectively implemented for online students to improve their skills during their academic life. If it is successful, Indonesian Open University can be better satisfied with their scholars' quality and sustainable outcomes. This study employed the literature study approach by obtaining the data and information from relevant previous studies. This study suggested that in order to enhance students' learning outcomes at UT, the instructors are expected to introduce the concept of critical thinking ability through learning content, instructional methods, practice examples and feedback. It is also suggested that students should be encouraged to participate in collaborative learning to stimulate their higher order thinking. The role of instructors and faculty member in designing engaging learning activities and providing accurate information related to learning management system are considerably crucial.
\end{abstract}

\section{Keywords}

critical thinking; distance learning; Indonesian Open University

\section{Introduction}

Critical thinking and distance learning are two popular terms in today's educational environment. Critical Thinking is a way of thinking required in higher education. Educators should encourage students to familiarize themselves with the nature of critical thinking. Critical thinking is ability to challenge the complexity of higher-order thinking which covers several ways such as analyzing, problem-solving, evaluating, judging, reflecting, and questioning (Carmichael \& Farrell, 2012). Simultaneously, online or distance learning is gaining its popularity as the result of globalized era and the advance of technology. The existence of online learning should foster the usefulness for people to get the opportunity to feel the atmosphere of higher education without worrying about the distance.

This article was raised from the issue related to the existence of Indonesia Open University or Universitas Terbuka (UT) as "mass university" in providing massive Open and Distance Learning. Therefore, UT is popularly known for its flexibility, inclusivity, and accessibility that can accommodate and provide opportunity for Indonesian citizen to get enrolled and involved in university and college experience. There is however concern from management and staff at the University about the quality of students' learning outcomes. These concerns relate to the crisis of UT students' quality and capability, in which students whose focus in on degree completion rather than learning outcomes. 
According to Setijadi (1988), this crisis is motived by two main reasons: (1) the unfamiliarity of students with distance learning environment; less "awareness" of "academic culture" among UT's staff; (2) technical and policy matters which relate to the use of ICT in education as primary distance learning media for UT's students.

This article purposes the enhancement of Critical Thinking skills for students of UT and argues that Critical Thinking can be effectively implemented for online students to improve their skills during their academic life. If successful, Indonesia Open University can be better satisfied with their scholars' quality and sustainable outcomes. For the next part of this article, there will be discussed about the (1) recent issues of Indonesia Open University (UT); (2) significances of critical thinking competence in improving students' learning outcomes and personal development in UT; (3) challenges faced by faculty members and also the recommendations offered to overcome the challenges.

Indonesia Open University or also called Universitas Terbuka (UT) was established in 1984 as the 45th state university to provide opportunity and access to university education, for in-service teachers, working adults and recent high school graduates. Universitas Terbuka (UT) becomes the implemented prototype of Open and Distance Learning or Pendidikan Terbuka dan Jarak Jauh (PTJJ). In higher education, distance learning is held to broaden the access to the university level, especially to overcome obstacles absorption capacity of high school graduates who are not accommodated in state higher education (face-to-face) and give an opportunity to those who are working to be able to follow higher education (Setijadi, 1988). Therefore, UT expectedly has major roles to play in developing high-calibre human resources needed for the nation's sustainable development.

Having seen from its terminology, UT which is based on Open and Distance Learning, is identically with "mass education". Organizationally, in educational management, UT cooperates with other private universities and other relevant institutions (Bank, Radio and Television Stations, and NonGovernmental Organizations) in order to assist the availability of teaching materials, exam materials, and implementation of the tutorial, practice/practicum. Practically, all learning activities in UT are done by accessing the Internet as a source to access non-printed materials (audio, video, electric modules, radio, and television). Open University, which is "open" here means there are no limitations of ages for the students, duration of study, the year of graduation, and length of examination as long as students in UT must have graduated from senior high school.

One of the characters of Distance Learning is there is a separation between teachers and students. Therefore, students at UT are forced to be independent during their learning process. This however put the students under the pressures. Students, in fact, are not prepared with the condition of distance learning, because they were accustomed to face-to-face learning pattern (Darmayanti, 1993; Kadarko, 2000; Kasworm, 1992). Thus, the lack of ability to adapt to independent in learning has become one of the aspects that contribute to the low learning achievement in the first year of a distance education student (Darmayanti, 1993; Indrawati, 1993). That kind of condition occurs because the independence of an individual characteristic is a crucial factor that can influence the learning process and learning achievement (Belawati, 1997; Syamsudin, 1984).

As a result, the root causes mentioned above bring UT to other crisis. UT now is dealing with the issue related to the quality of scholars. Some studies (Kadarko, 2000; Puspitasari \& Islam, 2003) report that Universitas Terbuka/UT (Indonesia Open University/IOU) student's learning performances are low to medium. It implied to their learning achievement, persistent; retention, and study completion. Carr (cited in Rovai, 2002) also noted that the number of persistence level of UT students in PTTJJ are 10$20 \%$ lower compared to other face-to-face colleges, which is more than $80 \%$; and $50 \%$ better in study completion. Moreover, the negative perception of students toward UT as "instant" campus to simply get the degree without paying attention to the learning process and outcome. Rector of Indonesia Open 
University, Tian Belawati (2011) postulated that the viewed lecture at UT is to simply get a diploma, instead of learning quality, still existed. Similarly, Sutawijaya (2016) as former Dean of UT hoped that UT's alumni can contribute to their country in solving the issue related human resource development to be competed in globalized era.

Actually, the recent issues occurred in UT are motivated by several previous problems. Mostly, learning process and other academic activities take place in UT are done online, so that it can cover all students around Indonesia. The experiences of UT in the use of internet in distance education might well illustrate the case, in which the use of internet in distance education has insignificant effect on the students. Very few students have accessed the UT online learning services, even though there are no fees charged to the students except for the cost of the internet connection. The major challenge for UT is to provide quality university education at a distance accessible by students with different level of economic capacity, access to ICT facilities and limited ICT literacy (Zuhairi, Adnan \& Thaib, 2007). This ironically describes the weakness or problem which cannot be maximally solved, whereas, in the other hand UT is very relying on the internet access covered in all areas in Indonesia.

The quality of scholars is reflected from quality of thoughts and students in higher education should empower the skill of higher level of their thinking. All those descriptions are reflected in one term, Critical Thinking. In the next part of this article, the author will discuss about the significance of Critical Thinking in higher education, especially in UT and further will examine how critical thinking values, concepts and behavior are implemented in Online based learning which is mostly used in UT learning environment.

\section{Method}

This article used the literature study approach. The data and information obtained for conducting this article were derived from mostly journal articles and books accessed in several journal article datab This study was intentionally conducted as the general analysis of implementation of critical thinkın ability in one particular distance learning setting, namely Indonesian Open University or popularly known as Universitas Terbuka (UT).

In presenting the finding, the descriptive review method was employed. According to Paré et al. (2015), a descriptive review was conducted as the series of analysis of the published literature providing a database from which the authors attempt to identify any interpretable trends or draw overall conclusions about the benefits of existing conceptualizations, propositions, methods or findings. In obtaining reliable information, the author searched for published literature and classify them into particular and desired topic. Having selectively classified the available literature, the author attempted to discuss issue of the study, analyse and identify some gap and draw conclusion related to the discussed topic, namely: critical thinking competence: significances in higher education; enhancing students' critical thinking in UT's distance learning environment; and challenges faced by educational practitioners in promoting students critical thinking through online learning at UT.

\section{Results and Discussion \\ Critical Thinking Competence: Significances in Higher Education}

What makes me sure to offer the critical thinking as a way to motivate students to contemplate and "appreciate" their learning outcome which finally improves the quality of UT's scholars? In this part of the article, the author will discuss my argument related to the significances of Critical Thinking as a competence which is highly recommended for Higher Education students, especially in Indonesia Open University. Critical thinking is universally recognised as a term which reflects the higher level of thinking. There is no a single exact answer in defining critical thinking. Many theorists have their own 
versions and point of views in giving the definition of critical thinking. One of those, Scriven and Paul (2003) described critical thinking as the intellectually disciplined process to conceptualize, apply, analyse, synthesize, and/or evaluate information collected from observation, experience, feedback, reasoning, or communication, as a way to believe and act. From that definition, critical thinking is associated with the complex steps of thinking processes and linked to the process of cognitive skill.

Seeing the essentiality offered by the critical thinking concepts, theorists now agree that critical thinking is supposed to be encouraged by the teachers to their students in higher education. Critical thinking ability is highly encouraged by educators for their students to challenge themselves to achieve critical values, the sense of creativity, and the requirement of high-order thinking (Harvey \& Kamvounias, 2008). For more convincing, Drake (1976) also added that Critical thinking is generally conceptualized as an intellectual ability suitable for development by those involved in higher education. The agreements made by theorists about implementing Critical Thinking skill in higher education also should be conceptualized even in UT as Open University.

Its relation to the recent condition in Indonesia Open University (UT), as being unsupervised and unmonitored by teachers, distanced students in UT need to improve their personality and the development of their academic achievement wherever they earn the knowledge, whenever they have time to learn, whatever types of information they get. As Leopold and Vickerman (2010) mentioned that Critical thinking becomes an umbrella term for different elements, which can include reflection, different thinking skills, personal development through experience and social situations. Moreover, students at UT are expected to be independent during their learning activity, individually or as a group. Working in a group requires the collaborative work among members. Students share their ideas, analyse them, debate each other, and surely it needs a critical thinking value. As Paul and Elder (2008) described that students who know how to analyze and critique ideas are able to make connections across disciplines, see knowledge as useful and applicable to daily life and understand content on a deeper, more lasting level. Moreover, critical thinking is the modal or offered option which can "solve" the issue happening in UT recently, in which a decreased quality of UT's scholars. As Peck (2012) mentioned the urgency with which stakeholders in education want students to graduate with critical thinking skills to compete in the expanding global economy. Evidently, other Open University, such as Open Universities Australia also emphasize of the invaluable role of critical thinking behaviour. By taking and completing the unit (provided by Macquarie University) which is implemented of critical concept, as the learning outcomes, students will learn how to (1) recognise the structure of arguments and them in clear and standardised form; (2) learn about reasoning skill; (3) apply the critical thinking analysis skill to real arguments form of variety contexts and other disciplines; (4) develop problem-solving skills and creative writing skills (www.open.edu.au/courses/arts/missing-unit--phi120-2015). Considering all explanations above, it is agreed that critical thinking is an ability or skill which is highly required to be implemented in students' academic performance in higher education level, especially in UT.

\section{Enhancing Students' Critical Thinking in UT's Distance Learning Environment}

As mentioned earlier, mostly learning activities conducted in Indonesia Open University (UT) is done online. In this part of the article, the author argues that Online Based Learning can be a good support in promoting students' critical thinking skill. Students in UT are expected to be independent in their distance learning. They access the learning material, module and additional information from the internet. This learning nature indirectly pushes students to be selective, open-minded, critical, in analysing, making a judgment, and deciding for the solution from varied information. This kind of activities is reflecting the "seed" of critical thinking concepts and behaviour. Therefore, critical thinking should be encouraged throughout every online education course for conveying information and enhancing discussions in an organized manner (Ricci, 2013). In addition to that, the accessibility, abundance, diversity, and rapidity of the information on the internet which is widely used by the 
students challenge themselves to renew and produce creative idea (Chang, 2012). To be creative is one of the criteria of critical thinking outcome.

Moreover, online learning is not simply defined as distance learning, in which students and instructor are separated or no single face-to-face meeting. Online learning is broadly referred to all activities which are conducted in certain digital learning platform, online software and application and other online discussion (teleconference and video recorded). Practically, by utilizing several learning platforms, students can implement several aspects of being critical thinker. Now UT has been empowering the MOOC (Massive Open Online Course) as media for students to access some course information and lesson. Hence, the use of digital learning platform such as Moodle is believed can help students to develop reasoning, problem-solving, and decision-making (Lopez et al. 2013). Additionally, as UT has also been empowering the use of its website to interact, students may be required to be creative in obtaining and analyzing information. Jang (2009) argues that the use of online (web-based) interaction can enhance students' creativity.

\section{Challenges Faced by Educational Practitioners in Promoting Students Critical Thinking Through Online Learning in UT}

Nevertheless, the author is aware of several factors that may become challenges for educationalist in enhancing critical thinking values in distance learning. In this part of this article, generally and basically, the author will examine several obstacles including the difficulties in (1) defining critical thinking culturally, theoretically, and practically, (2) considering some technical and methodological matters of using online based learning for both students and teachers. Firstly, critical thinking relates to the socio-cultural matter. According to the research conducted by Stapleton (2001), Asian countries, like Japanese students could not reflect the critical thinking concept in their English writing, because critical thinking which is Western oriented may differ with the Eastern educational culture. Thus, further, socio-culture matters to the selected topic as teaching material. Topic familiarity is the crucial factor in implementing reasoning skill. Stapleton's research revealed that the lack of critical thinking of Japanese ESL college students was displayed in the academic writing because they used American topic. It is not only happened in Japanese school, but also in Indonesia. Study from Samanhudi and Sampurna (2010) described the Indonesian EFL student from one of the universities located in Banten, indicated that students who do not have the prior knowledge or subject matter mastery gained through critical reading on the topic, will have problem to develop their critical thinking skill. Thus, online instructors, especially UT as the "mass distance" university, need to pay high attention in contextualizing and positioning themselves in teaching critical thinking in diversities.

Secondly, the higher educational practitioner including teachers and institutions are challenged to design and choose the proper methods and techniques in teaching critical thinking supported by online activity. The issue becomes more complicated because of the rapid growth of online learning in higher education and the emphasis of critical thinking. Traditional challenges in fostering critical thinking are compounded by a generalized lack of faculty familiarity with effective online instructional techniques (Mandernah et al. 2009). Evidently, the lack of familiarity with distance learning may affect students' learning behaviour, because they are used to interacting with a physical classroom and teachers. The recent issues taking place in UT now is that there are many students who are not capable of operating educational technology (Farisi, 2012) The other challenges also come from the massive distribution of UT students geographically over Indonesia which affect the way learners interact with each other. As UT is developed with Distance and Open Integrated Educational System (PTTJJ), there are limited academic and non-academic interaction among students and instructors. Hence, this factor becomes the factor of low persistence level, study completion, and the awareness of student organization (Belawati, 1995; Rovai, 2002). Those described ongoing condition, is technically reflected to the natural condition related to the technology mastery. 
Thirdly, the teachers in UT also need to be warned, as they possibly cannot provide an effective method in online learning. Some instructors seem to be unfamiliar in designing and deciding the best methods through online based activity for promoting critical thinking (Arend, 2009). To indicate, teachers are responsible in guaranteeing the availability of learning material, maintaining the learning activity (assessment, discussion and feedback). Teachers do not simply share the instruction, announce the assignment, and give the lecture and module to students, but teachers in distance learning are supposed to be the media user and developer that can keep the seriousness and commitment in maintaining the multi-ways interaction with students and other UT faculty members.

\section{Conclusion \& Suggestion \\ Conclusion}

To summarize, it is suggested that Critical Thinking offered to be implemented through Open and Distance Learning applied in UT to benefit the progress of students' learning outcomes and achievement. Every single online based media empowered by faculty members of Indonesia Open University are required to be supportive to implement the critical thinking concepts. The application MOOC (Massive Open Online Course) is beneficial for accommodating students all over Indonesia to obtain information, courses, and learning material. The Social Media Virtual Community Forum is important as media for multi-way communication among students' organization and UT staff. Teachers and academic member of UT become the crucial role in designing the proper methods through online based learning. Teachers need to be consistent and committed in order to keeping the sustainability of effective distance learning. There are however, other problems which should be resolved and surely, it will take much time. The Indonesian Government along with educational practitioners need to work cooperatively to preserve the future education, especially Indonesia Open University. There hopefully will be an unlimited access of internet, a sufficient support of other media technology and other modern facilities, so that students in every region of Indonesia can feel the atmosphere of "healthy" and "convenient" Open and Distance Education.

\section{Suggestion}

In addition to offering the critical thinking implementation through online learning applied in UT's way of teaching process in order to improve the quality of students' learning outcomes, this article also finally suggests for several recommendations for academic members, staff of Indonesia Open University to overcome the challenges in order to improve students' quality related to the learning achievement. Firstly, it is started from the enhancement students' critical thinking through online learning. The possible strategies encompass the selected method in teaching learning process, and other theoretical and technical approaches made by instructors in online classroom. Clark and Mayer (2008) suggested that beneath the e-learning architecture sit four key pedagogical considerations: content, instructional methods, practice examples and feedback. In terms of content, teachers are expected to introduce the critical thinking concepts in provided reading material and assignment to enhance students' understanding about critical thinking. Methodologically, teachers need to emphasize the collaborative work among students. Independently, by separating from teachers, students can work individually and collaboratively as group work. Collaborative work is one of the methods which reflects and requires the critical thinking competence. By working collaboratively, students can challenge arguments with other members, appreciate opinion, making judgments, and search for the solution. This, hopefully will improve students' learning motivation.

Secondly, gaining students' motivation and learning achievement are supposed to be fundamental and crucial in every higher education. Ideologically, based on Indonesia's Five Principle (Pancasila), Indonesia should build and develop citizens who have strong nation characters, highly valued behaviour, and morality (Saripudin, 2010). Students' learning outcomes and achievements are dependant on the academic cultural applied in the soul of the higher educationalists. Students will 
become of what are reflected from their teachers. Students will be motivated to learn and develop their academic performance if their teachers also show them how to get it. Therefore, in higher education, including UT, all academic and faculty members should implement, achieve, develop and strengthen the "university academic culture", as a part of the whole system of national education reforms (Undang-Undang No. 20, 2003). In Distance Education, improving students learning outcomes should rely on values, characters, educational ethics and development (Johnson, 2009; Johnson, Osguthorpe \& Williams, 2010). It is highly recommended to evaluate the faculty members' performance in preserving the "academic culture" in Distance Learning. Then, Farisi (2013) suggested to utilize the Learning Group Organizers (LGO) as a media to monitor or improve academic staffs' tangibles, reliability, responsiveness, assurance, empathetic in order to serve students with their participation in Open and Distance Learning (ODL), to provide the services related to the registration, learning supports, learning material, access to the internet, learning guidance, and independent task sheet provision. Thus, students' learning process and completion and learning achievement can be attained (Sugilar, 2000; Nurmawati, Handayani \& Rachmiazasi, 2002; Zaidin, Firman \& Sigit, 2003).

Distance Education reflected in UT also requires distance online forum as media to socially engage with other students, staff and instructors all over Indonesia. I completely suggest that UT has to empower the online forum as a media to maintain a communication integrated in an organisation to obtain the information, discuss certain topics and other needs in improving students' academic achievement. Farisi (2012) had investigated the effectiveness of using Social Media Virtual Community Forum for UT students to anticipate to anticipate the constraints of space and time interaction-communication. The existence of this social media forum community is intended to (1) overcome the obstacles of low interaction among students which is actually pushed in the effectuation of Open and Distance Learning (Belawati, 1995 \& Andriani, 2005); (2) to maximize the use of Information, Communication and Technology (ICT) which is seen as prime necessity to support the the development of independent learning of students in a more interactive format (Simoff \& Maher, 1997); (3) provide a potential social network for "community-building forces among students (James \& Bogan, 1995; Rovai, 2002; McKenzie \& Murphy, 2000; Dueber \& Misanchuk, 2001; Dawson, 2006).

Thirdly, teachers as instructors hold the crucial role in designing the activities in online learning. Some work urges instructors to adopt the role of online facilitator: This involves clarifying course topics, keeping the discussions on track, introducing opposing views to students, helping students navigate the online platform, and emphasizing good online behaviour (Hew, 2015). Responding to that statement, therefore, even without the presence of teachers in the learning meeting, teachers are expected to provide clear instruction, and information through dual interaction between students. Key to the success of a discussion in fostering students' higher-order thinking strategies is the instructor's interactivity in leading the discussion (Mandernach, 2006). Technically, a discussion made by teachers in online forum or digital learning platform is considered as effective method that can encourage students to behave critically. Therefore, Bai (2009) believed that well designed discussion questions are fundamental in developing critical thinking skills at high levels (p. 162). Overall, the separation between teachers and students in Open and Distance Learning applied in UT can be bridged through clear and integrated online discussion.

\section{References}

Andriani, D. (2005). Mahasiswa S2 pada sistem pendidikan jarak jauh: Pemanfaatan internet dan bantuan belajar. Jurnal Pendidikan Terbuka dan Jarak Jauh, 6(2), 77-91.

Arend, B. (2009). Encouraging critical thinking in online thread discussions. Journal of Educators Online, 6(1), 1-23. 
Arend, B. (2009). Encouraging critical thinking in online threaded discussions. The Journal of Educators Online, 6(1), 1-23.

Bai, H. (2009). Facilitating studentse critical thinking in online discussion: An instructor's experience. Journal of Interactive Online Learning, 8(2), 156-164.

Belawati, T. (1995). Increasing persistence in indonesian post-secondary distance education. Atheses submitted in partial fulfilment of the requirement for the degree of doctor of philosophy in Faculty of Graduate Studies (department of educational studies) at the University of British Columbia. Retrieved from: http://pustaka.ut.ac.id/puslata/pdf/81200.pdf

Belawati, T. (2011). UT hadapi tantangan kualitas. Retrieved from: http://edukasi.kompas.com/read/2011/09/04/2102428/UT.Hadapi.Tantangan.Kualitas.

Carmichael, E., \& Farrel, H. (2012). Evaluation of the effectiveness of online resources in developing student critical inking: review of literature and case study of a critical thinking online site. Journal of University Teaching \& Learning Practice, 9(1).

Chang, Y. S. (2012). Student technological creativity using online problem-solving activities. International Journal of Technology and Design Education, 23, 803- 816.

Clark, R. C., \& Mayer, R. E. (2008). E-learning and the science of instruction: Proven guidelines for consumers and designers of multimedia learning (2nd ed.). San Francisco, CA: John Wiley \& Sons, Inc.

Darmayanti, T. (1994). Readiness for self-directed learning and achievement the students universitas terbuka (the indonesian open learning university). Victoria, BC: unpublished Thesis Master. University of Victoria.

Darmayanti, T. (2002). Kemauan belajar (learning volition) mahasiswa pendidikan jarak jauh: studi kasus di universitas terbuka. Jurnal Pendidikan Terbuka aan Jarak Jauh, 3(1), 52-62.

Dawson, S. (2006). Online forum discussion interactions as an indicator of student community. Australasian Journal of Educational Technology, 22(4), 495- 510.

Dueber, B. \& Misanchuk, M. (2006). Sense of community in a distance education course. Paper presented at the Mid South Instructional Technology Conference, 8-10 April, Murfreesboro, TN. Retrieved from: http://bill.dueber.com/dueber-misanchuk.pdf.

Dunn, L. (2016). Teaching and digital technologies: big issues and critical questions, edited by M. Henderson, and G. Romeo. The Curriculum Journal, 1-2. doi:10.1080/09585176.2016.1180026

Farisi, M. I. (2012). Social relation networks in UT-online community forum. Turkish Online Journal of Distance Education, 13(2), 48-58.

Farisi, M. I. (2012). Social relation networks in UT-online community forum. Turkish Online Journal of Distance Education, 13(2), 48-58.

Farisi, M. I. (2013). Academic dishonesty in distance higher education: Challenges and models for moral education in the digital era. Turkish Online Journal of Distance Education, 14(4), 176195.

Farisi, M. I. (2013). Reforming Universitas Terbuka's academic culture through developing the values of character in learning group organizers. Asian Journal of Distance Learning, 11(1), 78-92

Harvey, A., \& Kamvounias, P. (2008). Bridging the implementation gap: a teacher-as- learner approach to teaching and learning policy. Higher Education Research and Development, 27(1), 31-41.

Haryono, A. (2001). Belajar Mandiri: Konsep dan penerapannya dalam sistem pendidikan dan pelatihan terbuka/jarak jauh. Jurnal Pendidikan Terbuka Dan Jarak Jauh, 2(2), 37-53.

Hew, K. F. (2015). Promoting engagement in online courses: What strategies can we learn from three highly rated MOOCS. British Journal of Educational Technology, 1-17.

Hew, K. F. (2015). Student perceptions of peer versus instructor facilitation of asynchronous online discussions: Further findings from three cases. Instructional Science, 43(1), 19-38.

Indonesian National Education Department. (2003). Undang-undang RI No.20 tahun 2003. Tentang sistem pendidikan nasional. 
Indrawati. 1993. Keterampilan Proses Sains. (online). Retrieved from: http://www.fisika smaonline.blogspot.com/2010/0 3/keterampilan-prosessains.html.

James, L. \& Bogan, K. (1995). Analyzing linkage structure in a course-integrated virtual learning community on the world wide web. Retrieved from: http://inet.nttam.com.

Jang, S. J. (2009). Exploration of secondary students' creativity by integrating web- based technology into an innovative science curriculum. Computers and Education, 52, 247-255.

Johnson, M. C., (2009). Character development in a distance education literature course: Perspectives on independent study English 395R--- Christian fantasy literaturem (Doctoral dissertation).

Retrieved from: http://gateway.proquest.com/openurl\%3furl_ver=Z39.88-

2004\%26res_dat=xri:pqdiss\%26rft_val_fmt=info:ofi/fmt:kev:mtx:dissertation $\% 26$ rft_dat=xri:pqdiss:3388258.

Johnson, M. C., Osguthorpe, R. D., \& Williams, D. D. (2010). The phenomenon of character development in a distance education course. Journal of College and Character, 11(1), 1-16.

Kadarko, W. (2000). Kemampuan belajar mandiri dan faktor-faktor psikososial yang mempengaruhinya: kasus universitas terbuka. Jurnal Pendidikan Terbuka Dan Jarak Jauh, 1(1), 27-41.

Kasworm, C. (1992). The development of adult learner autonomy and self-directedness in distance education. In Conference Abstracts: Distance education for the twenty-first century. Conference was held in the International Council for Distance Education, NonthaburiThailand.

Leopold, T., \& Vickerman, P. (2010). Learning and teaching guide on critical thinking. Hospitality, Leisure, Sport and Tourism Network. Retrieved from: http://heacademy.ac.uk/hlst/resources/sub-jectspecific guides.

Lopez-Perez, M. V., Perez-Lopez, M. C., \& Rodriguez-Ariza, L. (2011). Blended learning in higher education: studentse perceptions and their relation to outcomes. Computers \& Education, 56(3), 818-826.

Mandernach, B. J., Forrest, K. D., Babutzke, J. L., \& Manker, L. R. (2009). The role of instructor interactivity in promoting critical thinking in online and face-to-face classrooms. Merlot Journal of Online Learning and Teaching, 5(1).

McKenzie, W \& Murphy, D. (2000). I hope this goes somewhere: Evaluation of an online discussion group. Australian Journal of Educational Technology, 16(3), 239-257.

Norman J. Bauer (1977) Teaching Critical Thinking: Analyzing, Learning and Teaching Critical Thinking Skills by James A. Drake. Danville, II.: The Interstate Printers and Publishers, Inc., 1976. 237 pp. \$8.75, The Educational Forum, 41:4, 509-511.

Nurmawati., Handayani, S., \& Rachmiazasi, L. (2002). Pelayanan Universitas Terbuka dalam menyembut program S1-PGSD sebagai langkah menjemput bola lulusan D2-PGSD di Kabupaten Rembang. (Research report). Available from UT-Digital Library (Publication No. 70058).

Open Universities Australia. (2015). Critical thinking. Retrieved from: http://www.open.edu.au/courses/arts/missing-unit--phi120-2015).

Paré G., Trudel M.-C., Jaana M., Kitsiou S. (2015). Synthesizing information systems knowledge: A typology of literature reviews. Information \& Management, 52(2), 183-199.

Paul, R., \& Elder, L. (2008). Critical thinking: Strategies for improving student learning, Part II. Journal of Developmental Education, 32(2), 34-35.

Peck, J. J. (2012). Keeping it social: Engaging students online and in class. Asian Social Science, $8(14), 81-90$.

Phirangee, K., Demmans Epp, C., \& Hewitt, J. (2016). Exploring the relationships between facilitation methods, students' sense of community and their online behaviors. Online Learning, 20(2).

Puspitasari, K.A., \& Islam, S. 2003. Kesiapan belajar mandiri mahasiswa dan calon potensial mahasiswa pada pendidikan jarak jauh di Indonesia. Jurnal Pendidikan Terbuka dan Jarak Jauh. 4(1): 11-22. 
Ricci, A.F. (2009). Encouraging critical thinking in distance learning ensuring challenging intellectual programs. United States Distance Learning Association. 10(1), 1-15.

Rovai, A. (2002). Building sense of community at a distance. International Review of Research in Open and Distance Learning, 3(1). Retrieved from http://www.irrodl.org/content/v3.1/ rovai.pdf.

Samanhudi, U., \& Sampurna, P. (2010). Researching students ${ }^{\text {ee }}$ critical thinking in EFL writing class (a case study in English education department, Untirta). TEFLIN 57th Revitalizing Professionalism in ELT as a Response to Globalized World. Bandung, Indonesia: Indonesia University of Education.

Scriven, M., \& Paul, R. (2003). Defining critical thinking: A draft statement prepared for the National Council for Excellence in Critical Thinking Instruction. Retrieved from: http://www.criticalthinking.org/University/defining.html.

Setijadi. (1988). Indonesia: Universitas Terbuka. Prospects.

Simoff, S.J. \& Maher, L. (1997). Web-mediated course: The revolution in on-line design education. Retrieved from: http://ausweb.scu.edu.au/

Stapleton, P. (2001). Assessing critical thinking in the writing of Japanese university students: Insight about assumption and content familiarity. Written Communication, 18(4), 506-546.

Sugilar. (2000). Kesiapan belajar mandiri peserta pendidikan jarak jauh. Jurnal Pendidikan Terbuka dan Jarak Jauh. 1(2): 1-8

Syamsuddin, A. (1984). Psikologi pendidikan. Bandung: Institut Keguruan dan Ilmu Pendidikan.

Zaidin, M. A., Firman., \& Sigit, A. (2003). Studi tentang persepsi mahasiswa Universitas Terbuka terhadap pelayanan bahan ajar, tugas mandiri, dan internet di UPBJJ-UT Makassar. (Research Report). Available from UT- Digital Library (Publication No. 81871-1).

Zuhairi, A., Adnan, I. \& Thaib, D. (2007). Provision of student learning support services in a largescale distance education system at Universitas Terbuka, Indonesia. Turkish Online Journal of Distance Education, 8(4), 44-64. 